IZA DP No. 7812

The Polish Wage Curve: Micro Panel Data Analysis

Based on the Polish Labor Force Survey

Badi H. Baltagi

Bartlomiej Rokicki

December 2013 


\title{
The Polish Wage Curve: Micro Panel Data Analysis Based on the Polish Labor Force Survey
}

\author{
Badi H. Baltagi \\ Syracuse University \\ and IZA \\ Bartlomiej Rokicki \\ University of Warsaw
}

\section{Discussion Paper No. 7812 \\ December 2013}

\author{
IZA \\ P.O. Box 7240 \\ 53072 Bonn \\ Germany \\ Phone: +49-228-3894-0 \\ Fax: +49-228-3894-180 \\ E-mail: iza@iza.org
}

\begin{abstract}
Any opinions expressed here are those of the author(s) and not those of IZA. Research published in this series may include views on policy, but the institute itself takes no institutional policy positions. The IZA research network is committed to the IZA Guiding Principles of Research Integrity.

The Institute for the Study of Labor (IZA) in Bonn is a local and virtual international research center and a place of communication between science, politics and business. IZA is an independent nonprofit organization supported by Deutsche Post Foundation. The center is associated with the University of Bonn and offers a stimulating research environment through its international network, workshops and conferences, data service, project support, research visits and doctoral program. IZA engages in (i) original and internationally competitive research in all fields of labor economics, (ii) development of policy concepts, and (iii) dissemination of research results and concepts to the interested public.
\end{abstract}

IZA Discussion Papers often represent preliminary work and are circulated to encourage discussion. Citation of such a paper should account for its provisional character. A revised version may be available directly from the author. 
IZA Discussion Paper No. 7812

December 2013

\section{ABSTRACT}

\section{The Polish Wage Curve: Micro Panel Data Analysis Based on the Polish Labor Force Survey}

This paper analyzes the Polish wage curve using individual data from the Polish Labor Force Survey (LFS) at the 16 NUTS2 regions over the period 1999 - 2010. This survey does not gather information on wages of self-employed or paid family workers. After excluding the unemployed, inactive and missing observations, we are left with over 102,924 observations. We find evidence in favor of the Polish wage curve with an unemployment elasticity of -0.06 . We also find that males in Poland are significantly more responsive to local unemployment rates $(-0.08)$ than their female counterparts $(-0.04)$. Moreover, if the lagged unemployment rate is used as an instrument for current unemployment rate, we find that the unemployment elasticity increases substantially for less experienced and temporary workers.

JEL Classification: $\quad$ C26, J30, J60

Keywords: $\quad$ wage curve, fixed effects, regional labor markets

Corresponding author:

Badi H. Baltagi

Syracuse University

Department of Economics

Syracuse, New York 13244-1020

USA

E-mail: bbaltagi@maxwell.syr.edu 


\section{Introduction}

Blanchflower and Oswald (1990, 1995, 2000 and 2005) pioneered the study of wage curves at the micro level showing an empirically robust negative relationship between individual wages and regional unemployment rates. The estimates for unemployment elasticities varied across countries but lied mostly in the neighborhood of -0.1 . One explanation in the literature for such a negative relationship is the efficiency wage theory by Shapiro and Stiglitz (1984). In this case, there may be less need for firms to pay efficiency wages to their workers as the outside options of workers would decrease with higher unemployment rates. Alternatively, a higher unemployment rate may lead to a decline in workers' reservation wages, as it may affect job-finding opportunities negatively when they are laid off; see Blanchflower and Oswald (1995).

Previous literature on the wage curve for Poland include Blanchflower (2001), Iara and Traistaru (2004), Duffy and Walsh (2000, 2001) and Rogut (2007). The first two papers focus on estimating wage curves for a group of transition countries rather than Poland per se. More specifically, Iara and Traistaru (2004) use annual regional labour market data at the NUTS 3 level for Bulgaria, Hungary, Poland and Romania for the period from 1992 to 1999. They find that average earnings were negatively and significantly associated with regional unemployment rates in Bulgaria and Poland as suggested by the wage curve literature. For the period 1995-1998, for 49 regions (voivodships) in Poland, they find an unemployment elasticity of -0.07 based on 196 observations. In their study, Duffy and Walsh (2000) explore the determinants of average monthly wage levels across the same 49 (voivodships) regions of Poland over the period 1991-96. They find an unemployment elasticity of pay for Poland of 0.12. Finally, Duffy and Walsh (2001) use the Polish LFS data for the years 1994 to 1996. They excluded females arguing that they are more affected by short-term supply side considerations than their male counterparts. The total number of males in their panel was 14,203 . They find an estimated unemployment elasticity of pay of -0.11 .

Since the 1999 territorial reform, these 49 voivodhips no longer exist. This is why we use the 16 NUTS2 regions over the period $1999-2010$. Figure 1 gives the unemployment rate across these 16 NUTS2 regions over this period. Therefore, our results can be directly comparable to the ones obtained by Rogut (2007) who also studies wage curve with the NUTS2 level data over the period 1995-2005. 


\section{Put Figure 1 here}

Using average wages across regions and over time to estimate a wage curve has been criticized by Card (1995). Hence, in our study we use individual data from the Polish Labor Force Survey over the period 1999-2010. This rich micro-level dataset allows us to control for a large number of individual characteristics affecting individuals' wage responses to variations in regional unemployment rates. The sample used includes 102,924 observations of whom 53,886 are males and 49,038 are females. This data set allows us to control for region effects.

Using the fixed effects panel data estimator, we find evidence in favor of the wage curve for both male and female workers in Poland. This is in line with the empirical findings of Blanchflower and Oswald for several countries. Yet, our overall estimated elasticity is -0.06 which is substantially smaller than the one reported in previous studies. In particular, Rogut (2007) reports a much higher elasticity of -0.12 for the period 1995-2005.

We find that the unemployment elasticity of male wages in Poland over the period 1999-2010 is double the elasticity estimate for women. These results are in line with the findings by Card (1995) for the United States and Baltagi and Blien (1998) for West Germany. Moreover, if the lagged unemployment rate is used as an instrument for current unemployment rate, we find that the unemployment elasticity increases substantially for less experienced workers as well as temporary workers

\section{The model}

The wage curve is simply a standard wage equation normally used to estimate the returns to education or the male-female wage gap but with the addition of the local unemployment variable to the set of regressors. Following Blanchflower and Oswald (1995), we estimate the following wage curve for Poland:

$$
\log W_{i r t}=\alpha+\beta \log U_{r t}+X_{i r t}^{\prime} \gamma+\mu_{r}+\lambda_{t}+v_{i r t}
$$

where $W_{\text {irt }}$ is the real hourly wage rate of individual $i$ observed in region $r$ at time $t . U_{r t}$ is the unemployment rate in region $r$ at time $t . \mu_{r}$ is a region effect, $\lambda_{t}$ is a time effect and $v_{i r t}$ is the remainder error term. $X_{\text {irt }}$ represents control variables which include the characteristics of individual $i$ such as: gender, age, age squared, tenure, tenure squared, education, marital 
status, occupation, industry, sector, size of the employing firm, duration of the job and city size. See the Appendix for a detailed description of these variables. Our paper estimates a wage curve for Poland using micro-level wage data obtained from the Polish Labor Force Survey (LFS) at the 16 NUTS2 regions over the period 1999 - 2010. The survey does not gather information on wages of self-employed or paid family workers. After excluding the unemployed, inactive and missing observations, we are left with over 102,924 observations of whom 53,886 are males and 49,038 are females. This rich individual level data set allows us to control for a large set of individual characteristics affecting individuals' wage responses to variations in regional unemployment rates. We are able to investigate the existence of a wage curve for various types of workers: male vs. female, young vs. old, skilled vs. unskilled, etc.

\section{Empirical results}

Table 1 gives the estimation results for the unemployment elasticity of real wages $\beta$, for different types of workers using Equation (1) ${ }^{1}$. This is a standard fixed effects (FE) estimator with region and time fixed effects. With all individuals in our sample, the unemployment elasticity of real hourly wages is estimated as -0.056 and is significant at the $1 \%$ level. Robust standard errors are reported for all estimates. We also find that males in Poland are significantly more responsive to local unemployment rates (-0.078) than their female counterparts (-0.038). This is in line with the previous findings by Card (1995) for the United States and Baltagi and Blien (1998) for West Germany. Younger workers aged (15-29) have a significant unemployment elasticity of $(-0.078)$ and this increases to $(-0.084)$ for workers aged (30-44), becoming insignificant for workers above 45 years of age. As Duffy and Walsh (2001) argue much of the work experience gained under communism by older workers may not be rewarded so well in a market economy. ${ }^{2}$

This unemployment elasticity also varies depending on the worker's skill level, years of tenure, and whether this worker lives in a city or a village. It is insignificant for public sector

\footnotetext{
${ }^{1}$ In order to save space, we only report $\beta$. However, the results on the other control variables are available upon request from the authors.

${ }^{2}$ For the period 1994-1996, Duffy and Walsh (2001) argued that "under planning, most individuals stayed in the same job for the duration of their working age and the participation rate was high. Working age and job tenure were perfectly correlated." The transition period started to break down this traditional correlation and those that resisted job changes were in the older age groups.
} 
workers and for whether the employer is a small or a big firm (with 100 or more employees). Temporary workers' wages are more sensitive than permanent workers' wages with an unemployment elasticity of (-0.087) as compared to (-0.056). In summary, the existence of the Polish wage curve is confirmed for all categories considered except for workers over 45 years of age, public sector employees, micro enterprises and firms with 100 or more employees.

\section{Insert Table 1 here}

Next, we check the sensitivity of these results to using the lagged unemployment rate as an instrument for the current unemployment rate, see Baltagi and Blien (1998). These FE-2SLS estimates are shown in Table 1 right below the corresponding FE estimates. The results for all workers as well as men are about the same, but the elasticity for women becomes insignificant. The results remain significant for middle aged workers aged (30-44) and those who live in a village, as well as private sector workers, and those with more than 1 and less than 11 years of tenure. Also, those who work for medium sized firms. What is interesting is that temporary workers now have a much larger unemployment elasticity $(-0.127)$ as compared to $(-0.050)$ for permanent workers.

Having found that males in Poland are more sensitive to regional unemployment rates as compared to their female counterparts, we focus on finer groupings for males and females separately. Table 2 shows that young males aged (15-29) have the largest unemployment elasticity (-0.147). Men aged (30-44) have also a large and significant unemployment elasticity (-0.101), while men above 45 years of age are not sensitive to the regional unemployment rate. With FE-2SLS only men aged (30-44) have a significant unemployment elasticity (-0.098). Also, only the medium skilled men have a significant unemployment elasticity (-0.123). Men living in cities with less than 100k inhabitants and in villages have significant unemployment elasticities (-0.13 and -0.092 , respectively). Men with more than 1 and less than 11 years of tenure have a significant unemployment elasticity $(-0.095)$. Men in the private sector $(-0.093)$, men with temporary contracts $(-0.108)$ versus permanent contracts $(-0.077)$ and men working for medium size enterprises $(-0.095)$.

\section{Insert Table 2 here}

The results for women differ significantly from the ones obtained for men (see Table 3). First of all, the wage curve is found to be significant only in the case of middle aged women (30- 
$44)$ and only for the FE estimator (-0.068). Also, for low-skilled women (-0.069 for FE and 0.10 for FE-2SLS), women living in a village (-0.06 for FE) and women with medium level of tenure (-0.079 for FE). Women in the private sector (-0.065 for FE and -0.087 for FE-2SLS), women with permanent contracts $(-0.047$ for FE) and women with temporary contracts (0.134 for FE-2SLS). Also, women working for medium sized firms (-0.067 for FE).

Insert Table 3 here

\section{Conclusion}

Using a rich individual level data set from the Labor Force Survey in Poland, we show that the unemployment elasticity of hourly real wages in Poland is in line with the international evidence. However, it is significantly lower as compared to previous studies. Our data set allows us to estimate different wage curves with respect to age, education, experience and gender groups and urban vs. rural. Our results indicate that the wages of males in Poland are more sensitive to unemployment rates than wages of females for the period 1999-2010.

\section{References}

Baltagi, B.H., Blien, U., 1998. The German wage curve: evidence from the IAB employment sample. Economics Letters 61, 135-142.

Blanchflower, D.G., 2001. Unemployment, Well-Being, and Wage Curves in Eastern and Central Europe. Journal of the Japanese and International Economies 15, 364-402.

Blanchflower, D.G., Oswald, A.J., 1990. The wage curve. Scandinavian Journal of Economics 92, 215-235.

Blanchflower, D.G., Oswald, A.J., 1995. An introduction to the wage curve. Journal of Economic Perspectives 9, 153-167.

Blanchflower, D.G., Oswald, A.J., 2000. International wage curves. In Differences and Changes in Wage Structures, edited by Richard Freeman and Larry Katz, University of Chicago Press and NBER.

Blanchflower, D.G., Oswald, A.J., 2005. The wage curve reloaded. NBER Working Paper Series, Vol. w11338. Available at SSRN: http://ssrn.com/abstract=723307

Card, D., 1995. The wage curve: a review. Journal of Economic Literature 33, 285-299. 
Duffy, F., Walsh, P. P., 2000. A regional analysis of wage determination in Poland, LICOS Discussion Paper, No. 87.

Duffy, F., Walsh, P., 2001. Individual pay and outside options: Evidence from the Polish Labour Force Survey. IZA Discussion Paper 295.

Iara, A., Traistaru, I., 2004. How flexible are wages in EU accession countries? Labour Economics 11, 431-450.

Rogut, A., 2007. The Wage Curve in Poland in 1995-2005. Bank i Kredyt 38(4), 18-38. 


\section{Data Appendix}

The data set used in the present study is based on the fourth quarter of the Polish Labour Force Survey (LFS) for the period 1999-2010³. The survey does not gather information on wages of self-employed or paid family workers. After excluding the unemployed, inactive and missing observations, we are left with over 102,924 observations.

The data from the Polish Labour Force Survey provides information on the region (at the NUTS2 level) where the employee is located and the size of the city where he or she lives. Furthermore, the Survey gives data on personal characteristics, employment spell and employer. In this study we use individual net hourly wage deflated by the national consumer price index. We also apply the unemployment rate calculated on the basis of the LFS data, taken from the Polish Central Statistical Office for the population aged 15+.

The control variables used in the regressions are the following:

- $\quad$ Age of the individual

- $\quad$ Gender. Male $=0$ and female $=1$.

- Marital status. This variable includes 4 categories: Married, Single, Widow, Divorced.

- Education. This variable includes 7 different categories: higher (including second stage of tertiary education) $=7$, post-secondary $=6$, secondary vocational $=5$, general secondary $=4$, vocational $=3$, primary and lower secondary $=2$, incomplete primary and no education $=1$.

- Region. We distinguish among 16 Polish NUTS2 regions.

- City size. This variable includes 8 categories: city with population over 100 thousand $=7$, $50-99.9$ thousand $=6,20-49.9$ thousand $=5,10-19.9$ thousand $=4,5-9.9$ thousand $=3,2-4.9$ thousand $=2$, less than 2 thousand $=1$, village $=0$.

- The individual's years of tenure at the firm.

- $\quad$ Type of work. Permanent contract $=0$, temporary contract $=1$.

- Occupation. This variable includes 9 categories: representatives of the public authorities, senior officials and managers, specialists, technicians and other medium staff, office staff, personal services staff and dealers, farmers, gardeners, foresters and fishermen, industrial

\footnotetext{
${ }^{3}$ The survey is being conducted quarterly, so there are 4 data sets each year.
} 
workers and craftsmen, operators and assemblers of machinery and equipment, employed in elementary occupations.

- Industry classification. This variable defines the specific industry to which the employing establishment belongs, in accordance to the NACE rev. 1.1 classification. These include 15 categories such as: primary sector, mining and quarrying, manufacturing, electricity, gas and water supply, construction, trade and repair, hotels and restaurants, transport, storage and communication, financial intermediation, real estate, renting and business activities, public administration, education, health care and social work, other community, social and personal service activities, households.

- Firm size. This variable includes 5 categories: up to 10 employees $=1,11-19$ employees $=2,20-49$ employees $=3,50-100$ employees $=4$, over 100 employees $=5$.

- $\quad$ Sector . Public $=0$, private $=1$.

\section{Summary statistics}

$\begin{array}{llllrr}\text { Variable } & \text { Obs } & \text { Mean } & \text { Std. Dev. } & \text { Min } & \text { Max } \\ \text { region } & 102924 & 16.87016 & 9.333652 & 2 & 32 \\ \text { citysize } & 102924 & 3.558908 & 2.932758 & 0 & 7 \\ \text { year } & 102924 & 2004.214 & 3.471274 & 1999 & 2010 \\ \text { gender } & 102924 & 0.476449 & 0.499448 & 0 & 1 \\ \text { age } & 102924 & 39.11169 & 10.73141 & 15 & 74 \\ \text { marital status } & 102924 & 0.369302 & 0.717564 & 0 & 3 \\ \text { education } & 102924 & 4.433699 & 1.625184 & 1 & 7 \\ \text { sector } & 102924 & 0.579185 & 0.493692 & 0 & 1 \\ \text { section } & 102924 & 10.08004 & 4.008244 & 2 & 18 \\ \text { firmsize } & 102924 & 3.360344 & 1.495728 & 1 & 5 \\ \text { typeofwork } & 102924 & 0.192414 & 0.394198 & 0 & 1 \\ \text { tenure } & 102924 & 9.428034 & 9.439289 & 0 & 53 \\ \text { unemployment rate } & 102924 & 14.93793 & 5.264154 & 5.5 & 26.3 \\ \text { occupation } & 102924 & 3.715013 & 2.512657 & 0 & 8 \\ \text { hourly wage } & 102924 & 25.61068 & 14.29592 & 10 & 150\end{array}$


Figure 1: Regional Unemployment in Poland, 1998-2010

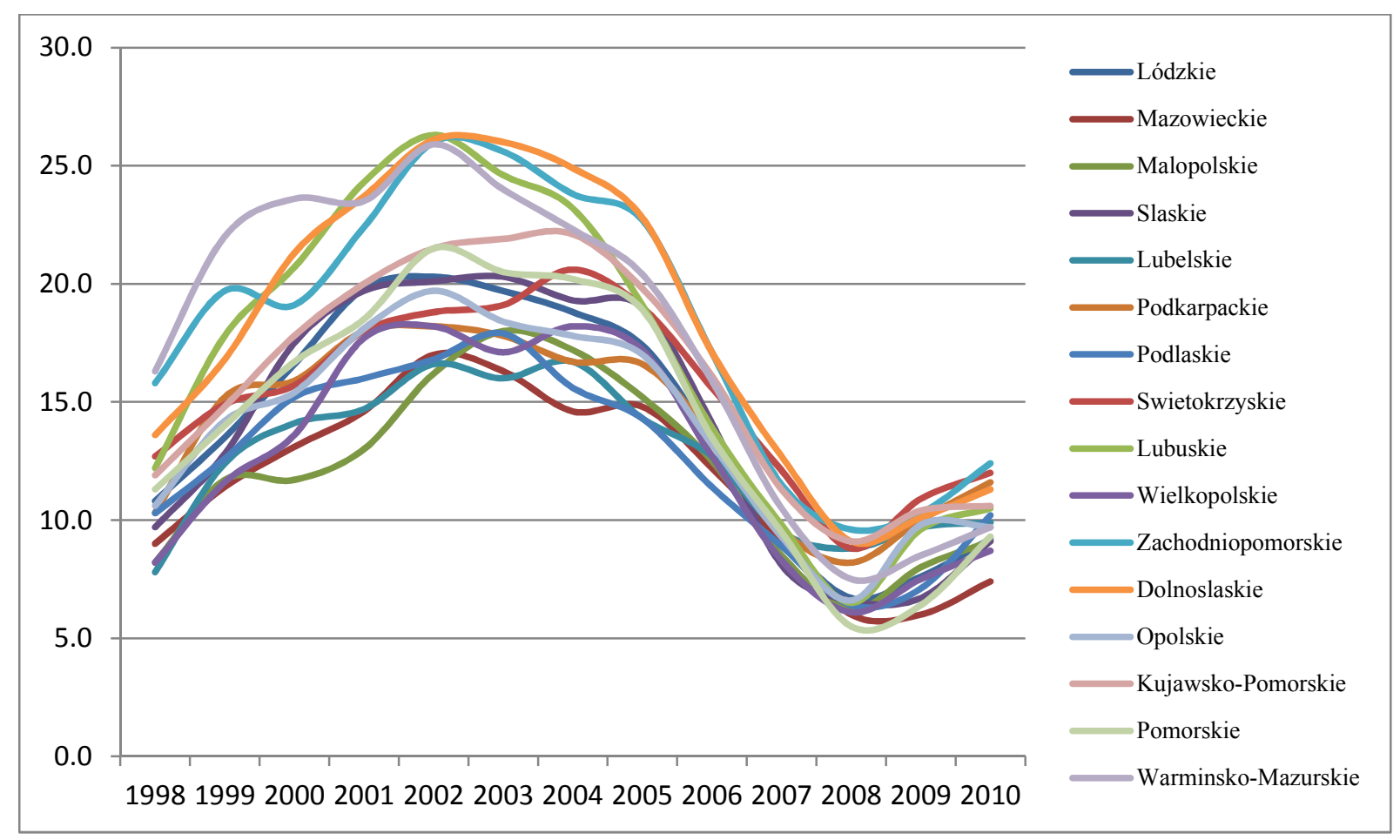

Source: This is based on data from the Polish Central Statistical Office 
Table 1

The Polish unemployment elasticity of real hourly wages by worker type

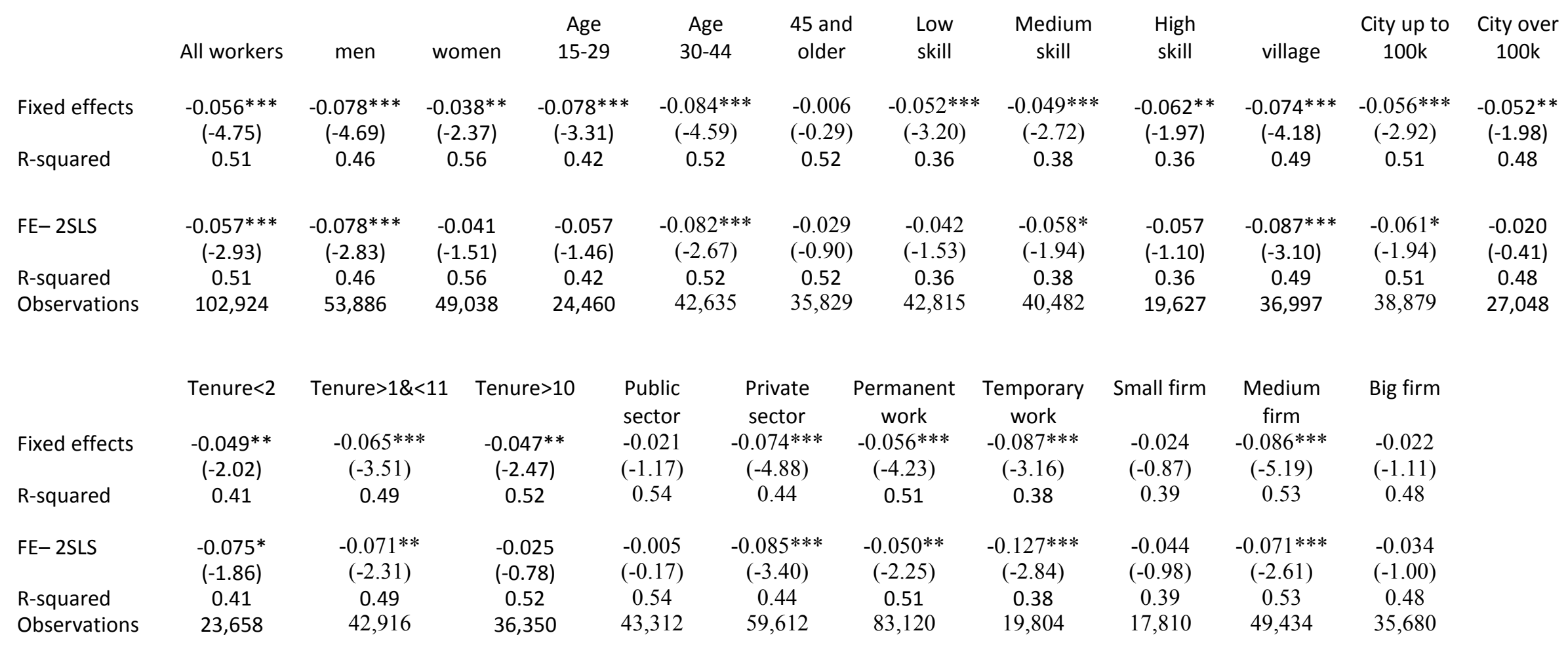

Notes:

a) See Appendix for sample coverage.

b) t-statistics in parentheses based on robust standard errors. *, ** and $* * *$ represent significance at $10 \%, 5 \%$ and $1 \%$, respectively.

c) Low skill workers refer to individuals with vocational, lower secondary, primary or no education. Medium skill workers refer to individuals with post-secondary (nontertiary), vocational secondary or secondary education. High skill workers refer to tertiary and higher education attainment.

d) Small firms refer to enterprises with up to 10 employees. Medium firms refer to enterprises with more than 10 and up to 100 employees. Big firms refer to enterprises with more than 100 employees.

e) In FE-2SLS specification, the logarithm of unemployment rate by region in the previous year has been used as an instrument for the logarithm of unemployment rate by region at time $t$. 


\section{Table 2}

The Polish men unemployment elasticity of real hourly wages by worker type

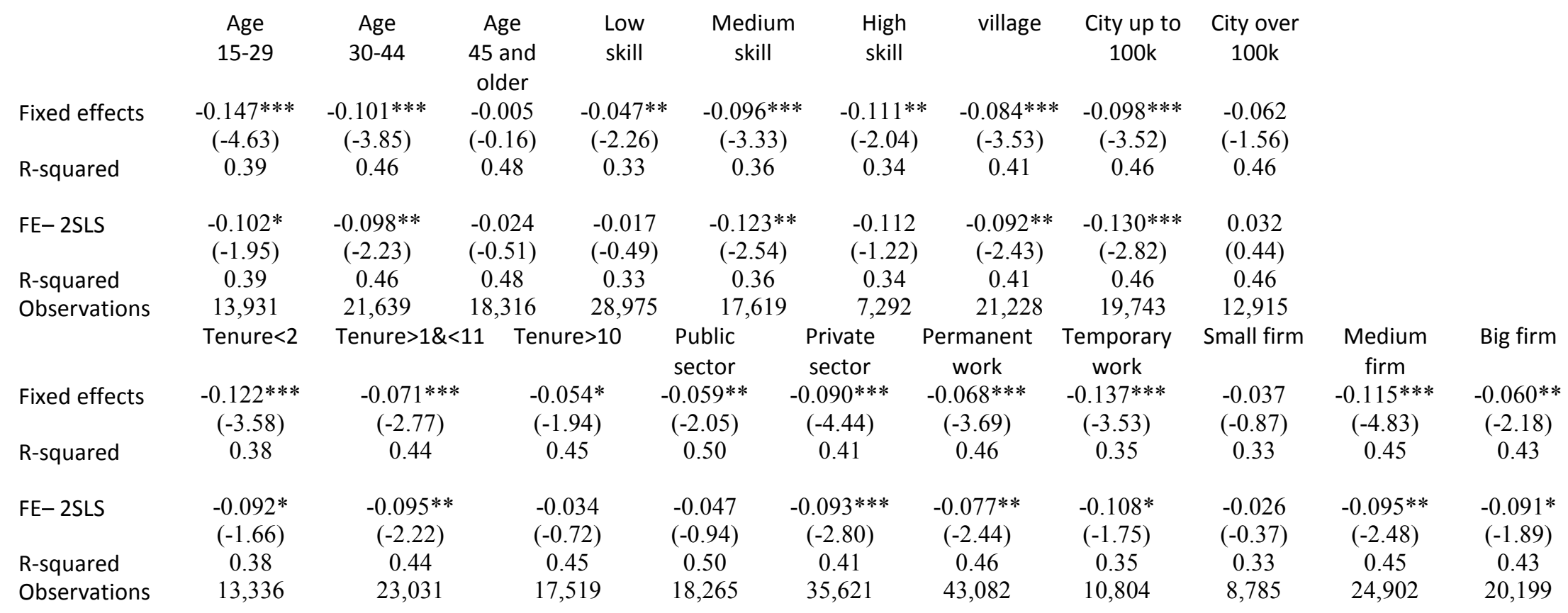

Notes:

a) See Appendix for sample coverage.

b) t-statistics in parentheses based on robust standard errors. * ** and $* * *$ represent significance at $10 \%, 5 \%$ and $1 \%$, respectively.

c) Low skill workers refer to individuals with vocational, lower secondary, primary or no education. Medium skill workers refer to individuals with post-secondary (nontertiary), vocational secondary or secondary education. High skill workers refer to tertiary and higher education attainment.

d) Small firms refer to enterprises with up to 10 employees. Medium firms refer to enterprises with more than 10 and up to 100 employees. Big firms refer to enterprises with more than 100 employees.

e) In FE-2SLS specification, the logarithm of unemployment rate by region in the previous year has been used as an instrument for the logarithm of unemployment rate by region at time $t$. 


\section{Table 3}

The Polish women unemployment elasticity of real hourly wages by worker type

\begin{tabular}{|c|c|c|c|c|c|c|c|c|c|c|c|}
\hline & $\begin{array}{l}\text { Age } \\
15-29\end{array}$ & $\begin{array}{l}\text { Age } \\
30-44\end{array}$ & $\begin{array}{c}\text { Age } \\
45 \text { and } \\
\text { older }\end{array}$ & $\begin{array}{l}\text { Low } \\
\text { skill }\end{array}$ & $\begin{array}{l}\text { Medium } \\
\text { skill }\end{array}$ & $\begin{array}{l}\text { High } \\
\text { skill }\end{array}$ & village & \multicolumn{2}{|c|}{$\begin{array}{l}\text { City over } \\
100 \mathrm{k}\end{array}$} & & \\
\hline Fixed effects & $\begin{array}{l}-0.009 \\
(-0.25)\end{array}$ & $\begin{array}{c}-0.068 * * * \\
(-2.76)\end{array}$ & $\begin{array}{l}-0.016 \\
(-0.59)\end{array}$ & $\begin{array}{c}-0.069 * * * \\
(-2.82)\end{array}$ & $\begin{array}{l}-0.014 \\
(-0.63)\end{array}$ & $\begin{array}{l}-0.047 \\
(-1.27)\end{array}$ & $\begin{array}{c}-0.060 * * \\
(-2.31)\end{array}$ & $\begin{array}{l}-0.017 \\
(-0.65)\end{array}$ & $\begin{array}{l}-0.056 \\
(-1.63)\end{array}$ & & \\
\hline R-squared & 0.48 & 0.60 & 0.58 & 0.25 & 0.38 & 0.39 & 0.60 & 0.57 & \multicolumn{2}{|l|}{0.52} & \\
\hline $\mathrm{FE}-2 \mathrm{SLS}$ & $\begin{array}{l}-0.016 \\
(-0.29)\end{array}$ & $\begin{array}{l}-0.059 \\
(-1.43)\end{array}$ & $\begin{array}{l}-0.047 \\
(-1.07)\end{array}$ & $\begin{array}{c}-0.100 * * \\
(-2.41)\end{array}$ & $\begin{array}{l}-0.004 \\
(-0.10)\end{array}$ & $\begin{array}{l}-0.053 \\
(-0.85)\end{array}$ & $\begin{array}{c}-0.073^{*} \\
(-1.76)\end{array}$ & $\begin{array}{l}0.001 \\
(0.03)\end{array}$ & $\begin{array}{l}-0.073 \\
(-1.19)\end{array}$ & & \\
\hline R-squared & 0.48 & 0.60 & 0.58 & 0.25 & \multirow{2}{*}{$\begin{array}{c}0.38 \\
22,863\end{array}$} & 0.39 & 0.60 & 0.57 & \multirow{2}{*}{$\begin{array}{c}0.52 \\
14,133\end{array}$} & & \\
\hline \multirow[t]{2}{*}{ Observations } & 10,529 & 20,996 & 17,513 & 13,840 & & 12,335 & 15,769 & 19,136 & & & \\
\hline & Tenure $<2$ & Tenure $>1 \&<11$ & 1 Ter & $r e>10$ & $\begin{array}{l}\text { Public } \\
\text { sector }\end{array}$ & $\begin{array}{l}\text { Private } \\
\text { sector }\end{array}$ & $\begin{array}{l}\text { Permanent } \\
\text { work }\end{array}$ & $\begin{array}{c}\text { Temporary } \\
\text { work }\end{array}$ & Small firm & $\begin{array}{l}\text { Medium } \\
\text { firm }\end{array}$ & Big firm \\
\hline Fixed effects & $\begin{array}{l}0.039 \\
(1.13)\end{array}$ & $\begin{array}{c}-0.079 * * * \\
(-3.03)\end{array}$ & & $\begin{array}{l}036 \\
.41)\end{array}$ & $\begin{array}{l}-0.001 \\
(-0.05)\end{array}$ & $\begin{array}{c}-0.065 * * * \\
(-2.86)\end{array}$ & $\begin{array}{c}-0.047 * * * \\
(-2.60)\end{array}$ & $\begin{array}{l}-0.024 \\
(-0.65)\end{array}$ & $\begin{array}{l}-0.027 \\
(-0.73)\end{array}$ & $\begin{array}{c}-0.067 * * * \\
(-2.93)\end{array}$ & $\begin{array}{l}0.010 \\
(0.33)\end{array}$ \\
\hline R-squared & 0.47 & 0.54 & & 58 & 0.59 & 0.46 & 0.57 & 0.44 & 0.45 & 0.61 & 0.51 \\
\hline $\mathrm{FE}-2 \mathrm{SLS}$ & $\begin{array}{l}-0.042 \\
(-0.74)\end{array}$ & $\begin{array}{l}-0.062 \\
(-1.42)\end{array}$ & & $\begin{array}{l}010 \\
.23)\end{array}$ & $\begin{array}{l}0.017 \\
(0.43)\end{array}$ & $\begin{array}{c}-0.087 * * \\
(-2.33)\end{array}$ & $\begin{array}{l}-0.025 \\
(-0.83)\end{array}$ & $\begin{array}{c}-0.134 * * \\
(-2.14)\end{array}$ & $\begin{array}{l}-0.079 \\
(-1.32)\end{array}$ & $\begin{array}{l}-0.056 \\
(-1.50)\end{array}$ & $\begin{array}{l}0.009 \\
(0.19)\end{array}$ \\
\hline R-squared & 0.47 & 0.54 & & .58 & 0.59 & 0.46 & 0.57 & 0.44 & 0.45 & 0.61 & 0.51 \\
\hline Observations & 10,322 & 19,885 & & 831 & 25,047 & 23,991 & 40,038 & 9,000 & 9,025 & 24,532 & 15,481 \\
\hline
\end{tabular}

Notes:

a) See Appendix for sample coverage.

b) t-statistics in parentheses based on robust standard errors. * ,** and $* * *$ represent significance at $10 \%, 5 \%$ and $1 \%$, respectively.

c) Low skill workers refer to individuals with vocational, lower secondary, primary or no education. Medium skill workers refer to individuals with post-secondary (nontertiary), vocational secondary or secondary education. High skill workers refer to tertiary and higher education attainment.

d) Small firms refer to enterprises with up to 10 employees. Medium firms refer to enterprises with more than 10 and up to 100 employees. Big firms refer to enterprises with more than 100 employees.

e) In FE-2SLS specification, the logarithm of unemployment rate by region in the previous year has been used as an instrument for the logarithm of unemployment rate by region at time $t$. 